Series on the Iraq War and its Consequences - Vol. 2

\title{
Iraq Beyond the Headlines
}

History, Archaeology, and War 


\section{Series on the Iraq War and its Consequences}

(ISSN: 1793-1711)

\section{Published}

\section{Vol. 1}

The Iraq War and its Consequences: Thoughts of Nobel Peace Laureates and Eminent Scholars

edited by Irwin Abrams \& Wang Gungwu

An extraordinary collection of essays on the recently concluded Iraq War by Nobel Peace laureates and leading scbolars. The Iraq War and its Consequences is the first and only book that brings together more than 30 Nobel Peace laureates and eminent scholars to offer opinions, analyses and insights on the war that bas drawn both widespread opposition and strong support.

Vol. 2

Iraq Beyond the Headlines: History, Archaeology, and War by Benjamin R Foster, Karen Polinger Foster \& Patty Gerstenblith 
Series on the Iraq War and its Consequences - Vol. 2

\section{Iraq Beyond the Headlines}

History, Archaeology, and War

Benjamin R. Foster

Yale University

Karen Polinger Foster

Yale University

Patty Gerstenblith

DePaul University

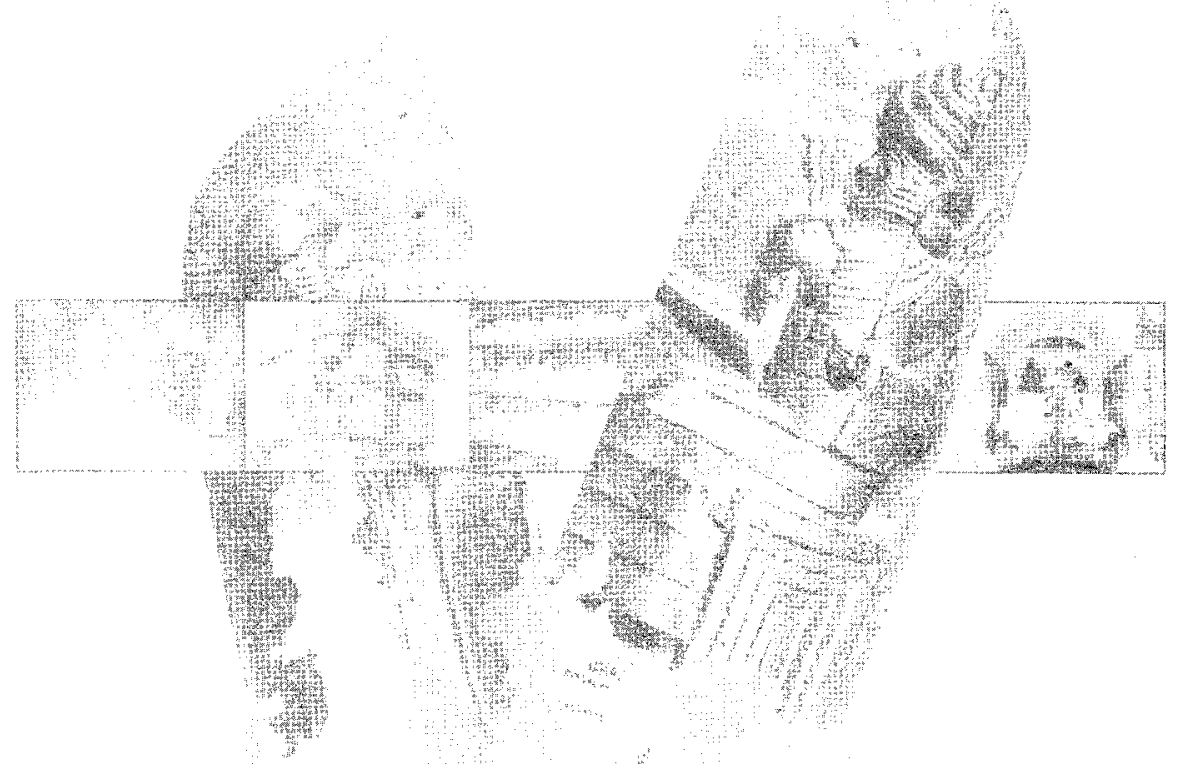




\section{Published by}

World Scientific Publishing Co. Pte. Ltd.

5 Toh Tuck Link, Singapore 596224

USA office: 27 Warren Street, Suite 401-402, Hackensack, NJ 07601

UK office: 57 Shelton Street, Covent Garden, London WC2H 9HE

\section{British Library Cataloguing-in-Publication Data}

A catalogue record for this book is available from the British Library.

\section{IRAQ BEYOND THE HEADLINES: HISTORY, ARCHAEOLOGY, AND WAR}

Copyright $\odot 2005$ by World Scientific Publishing Co. Pte. Ltd.

All rights reserved. This book, or parts thereof, may not be reproduced in any form or by any means, electronic or mechanical, including photocopying, recording or any information storage and retrieval system now known or to be invented, without written permission from the Publisher.

ISBN 981-256-379-2 (pbk) 


\section{Contents}

List of Illustrations

Preface

Chapter 1 Beginnings, Modern and Ancient

Chapter 2 Early City States and Empires

Chapter 3 The Age of Hammurabi

Chapter 4 A Babylonian Nation-State

Chapter 5 The Assyrian Achievement

Chapter 6 Babylon and Her Empire

Chapter 7 Mesopotamia between Two Worlds

Chapter 8 Iraq between Iran and Arabia

Chapter 9 The Muslim Conquest of Iraq

Chapter 10 The Age of Baghdad and Samarra

Chapter 11 Iraq in the Ottoman Empire

Chapter 12 Colonization and Monarchy 
Chapter 13 The Republic of Iraq

Chapter 14 Archaeology Past and Present in Iraq

Chapter 15 The Iraq Museum and the Future of the Past

Chapter 16 International and National Legal Regimes for the Protection of Archacological Heritage

Appendix Iraqi Libraries, Research Centers, and Centers for the Arts 


\section{List of Illustrations}

Map showing major sites and excavators (underlay map after Seton Lloyd, The Archaeology of Mesopotamia [London: Thames and Hudson, 1978], fig. 2).

Alabaster vase from Uruk (after Eva Strommenger, Fünf Jabrtausende Mesopotamien [Munich: Hirmer, 1962], pl. 19).

Overturned exhibit case with the Uruk vase base in the Iraq Museum, October 2003 (photo Catherine Sease).

Uruk vase fragments back in the Iraq Museum, October 2003 (photo Catherine Sease).

Alabaster head from Uruk (after Eva Strommenger, Fünf Jabrtausende Mesopotamien [Munich: Hirmer, 1962], pl. 31).

Uruk head returned to the Iraq Museum, October 2003 (photo Catherine Sease).

Diorite statue of Enmetena from Ur (after Anton Moortgat, The Art of Ancient Mesopotamia [London: Phaidon, 1969], pl. 87).

Inlaid harp from Ur (after C. Leonard Woolley, Ur Excavations: The Royal Cemetery [Oxford: Oxford University Press, 1934], pl. 114).

Harp and other damaged pieces in the Iraq Museum, October 2003 (photo Catherine Sease). 
Copper-alloy statue made for Naram-Sin (after Joan Oates, Babylon [London: Thames and Hudson, 1979], 35).

Gouged stairs in the Iraq Museum, October 2003

(photo Catherine Sease).

$\frac{\dot{s}}{\stackrel{0}{L}}$ Ivory furniture panel from Nimrud (after Paolo Matthiae, La storia dell'arte dell'Oriente Antico: I primi imperi e $i$ principati del ferro

[Milan: Electa, 1997], 181, Photoservice Electa, Milan).

范

OD. Damaged ivories in the Iraq Museum, October 2003

(photo Catherine Sease).

Eylinder seals from Kish and Girsu (after Eva Strommenger,

Der Garten in Eden [Berlin: Museum für Vor- und Frühgeschichte

.

Storage cabinets in the Iraq Museum, October 2003

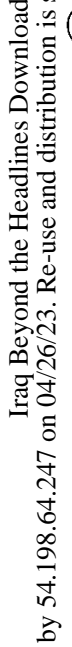




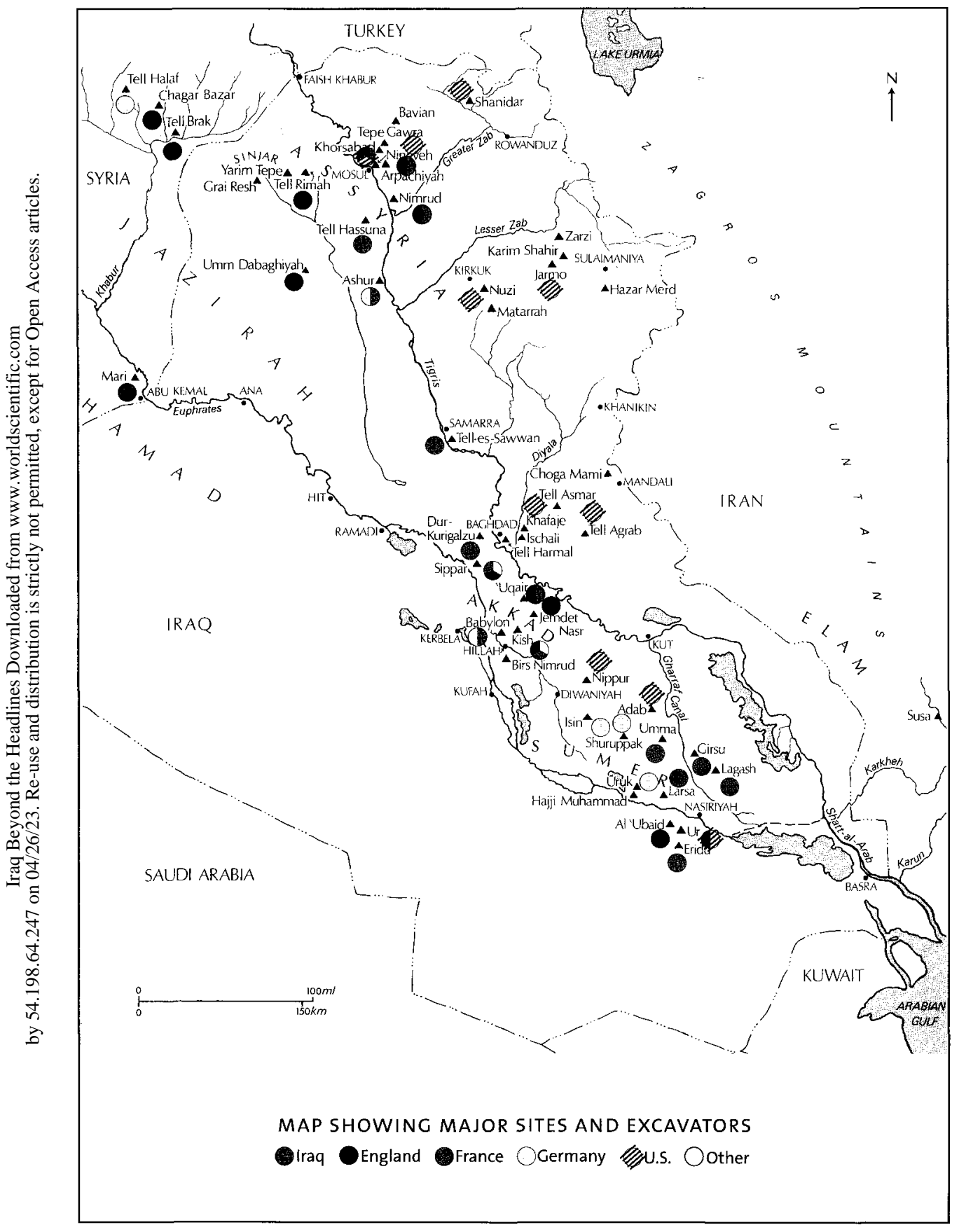


This page is intentionally left blank 


\section{Preface}

This book offers a brief historical and cultural survey of the land of Iraq culminating with the American-led invasion and occupation of that country in 2003. Its focus is on the discovery, management, preservation, and destruction of cultural heritage of all periods, especially pre-Islamic antiquity. To this end, it gives a bricf account of the political and social history of the region, with special reference to archaeological discoveries and their interpretation, and discusses modern law governing the exploitation of cultural heritage. It is intended for readers with no prior knowledge of these subjects. Studies of warfare generally overlook its cultural consequences, preferring to focus on victory and defeat, strategy and tactics, and redefinitions of government, economy, and society in the aftermath. Yet often the cultural impact of war, in the long term, far outweighs other considerations. Military victories and defeats are replaced by other victories and defeats, but cultural destruction is permanent and irremediable.

Modern technology and weaponry, and their easy availability to anyone, mean that cultural achievements are increasingly at the mercy of people who wish to force their own vision on a landscape, tegardless of consequences. The Gulf and Iraq wars highlight this, as they have taken an as yet unknown toll of the human past of all periods, from the dawn of society to the last century, opening the way to a frenzy of looting of ancient sites and museums in Iraq on a scale the world has never seen. This is far more than scavenging surreptitiously for pots in ancient mounds. Rather, thieves use heavy equipment, large, armed teams of men, satellite telephones, containerized airfreight, and the Internet. Their highly lucrative trade is sustained and paid for by collectors and museums in the Middle East, Europe, the United States and Canada, and Japan for whom the vanity of ownership prevails over all other considerations. 
The book is a team effort by an Assyriologist, Benjamin R. Foster (Chapters 1-13), an art historian/archaeologist, Karen Polinger Foster (Chapters 14, 15), and an attorney/archaeologist, Patty Gerstenblith (Chapter 16), to shed light on the cultural and legal consequences of these wars in Iraq. It takes no position on the wars themselves but seeks to answer the questions often asked of us: "So what's the importance of this looting? What real difference does it make?" Our thesis is that the recent, on-going cultural destruction wrought on Iraq is ¿as important as any strategic, political, economic, or environmental outcomes \&of these two wars. The loss of cultural memory and achievement is permanent, ฐ̃ and much of it could have been avoided even in wartime conditions. The United States military in the Second World War amassed a brilliant record in protecting ofcultural property and restoring it to its owners, against a background of systematic ङlooting of cultural property by other powers, especially the German and Russian . military and governments.

This record stands now in stark contrast to the ignorance, lack of planning, and unwillingness to act in cultural matters, which characterized the American Ineadership, especially in the Iraq War and during the subsequent American Foccupation of the country. Unlike many armies, the American forces themselves . did little looting in these wars, but they did almost nothing to stop it either. The 贾looting has been done mainly by Iraqis to make much-needed money from the international trade in antiquities and other cultural property. In a few years, as Fill show, Iraq went from having one of the best-protected ancient heritages Forst. No understanding of the American 要 military involvement in the Middle East can be sound or complete without an 位appreciation of its long-term cultural impact.

Forts of this book originated in the McKee-May Academic Lectures, delivered oby Benjamin R. Foster in Greenwich, CT, in the winter of 2004. Our thanks go It to Jennifer Vietor Evans of Greenwich for the invitation that made possible this oundertaking. Bassam Frangieh of Yale University was characteristically generous with his time and knowledge in discussing and checking the translations from A Arabic poetry given here, and for advising on suitable selections. Poetry is widely appreciated in the Arabic-speaking world as a form of cultural and social expression, so the purpose here has been to offer some hint of its enormous richness and variety. Beatrice Gruendler drew attention to the lament of al-Rumi and allowed use of her unpublished translation. Sasha Treiger kindly checked a translation from Russian. 
The book has greatly benefited from discussions with colleagues during several conferences and panels on the issues, among them "A Future for Our Past: An International Symposium for Redefining the Concept of Cultural Heritage and its Protection," held in Istanbul in June 2004; and three programs, "Iraq Beyond the Headlines," held at Yale University in April 2003, October 2003, and October 2004. Joanne Farchakh read critically Chapters 14 and 15. Catherine Sease, Dominique Collon, Zainab al Bahrani, Eva Strommenger, and Roger Atwood assisted generously with photographs. Peter W. Johnson digitized the map and designed the cover. The authors are grateful to Kimberly Chua and the staff of World Scientific for suggesting this project and for seeing it through.

January 2005 